\title{
Condition, Regional Disparity And Strategic Priorities Of Providing Technological Competitiveness Of Ukraine's Economy
}

\author{
Svitlana Lykholat ${ }^{1}$, Volodymyr Zaichenko ${ }^{2}$ Nataliya Rozhko ${ }^{3}$ \\ ${ }^{1}$ Department of Marketing and Logistics, Institute of Economics and Management, Lviv Polytechnic National University \\ Bandera street, 12, Lviv, 79013 - Ukraine \\ ${ }^{2}$ Faculty of Economics and Management, Central Ukrainian National Technical University \\ 8, Prospekt Universytetskyi, 8, Kropyvnytskyi, 25006 - Ukraine \\ ${ }^{3}$ Department of Industrial Marketing, Faculty of Economics and Management, Ternopil Ivan Pului National Technical \\ University \\ Ruska street, 56, Ternopil, 46001 - Ukraine
}

\begin{abstract}
The proper role and high importance of regional peculiarity of innovation and technological activity in the context of ensuring technological competitiveness of the economy depends on its identification and understanding of the critical differentiation of the regions of Ukraine by the number of innovatively active enterprises, production volumes, share of realized innovative products, as well as the positioning the regions of Ukraine by the share of enterprises with technological innovations, the rate of its growth and the share of realized innovative products in the total volume of industrial products sold. It is shown that the modern policy of ensuring technological competitiveness of the Ukrainian economy is formed in the context of contemporary challenges of global competition, fundamental features, which are the impact of global crises, financial and economic instability; increase of external expansion due to processes of globalization, development of information economy; pressure on the country's debt; increase in import dependency; high external labour migration activity; destabilization of economic development through military conflict and hybrid attacks; critical disparities in regional development. The strategic priorities of the state policy of ensuring technological competitiveness of the Ukrainian economy have been determined: intensification of technological development of the economy, growth of the general level of innovative activity, formation of a competitive market of intellectual property, development of infrastructure for support of technological innovations, improvement of resource provision of innovative activity, improvement of business parameters of competition.
\end{abstract}

Index Terms - technological competitiveness, strategic priorities, economic growth, technological innovations, small and mediumsized enterprises, modernization of the economy

ASEJ - Scientific Journal of Bielsko-Biala School of Finance and Law

Volume 24, No 1 (2020), 5 pages

DOI: $10.5604 / 01.3001 .0014 .1350$

Received: 27 March 2020; Accepted: 30 March 2020

\section{INTRODUCTION}

The state policy of ensuring the technological competitiveness of the economy is objectively and lawfully oriented towards creating such conditions under which the leading share of the gross national product in terms of price characteristics, quality and other consumer parameters is dominated by direct and indirect competitors both in the domestic and foreign product markets (provision of services). The focus is not on the natural, speculative or conjuncture aspects, but on achieving the relevant benefits by creating, engaging, testing, acquiring and using technological innovations. It is a question of application of modern technologies both in product development, and in its production, in technological business processes, in competition policy, and directly in the formation of properties of goods, works, and services. The task of ensuring the technological competitiveness of the Ukrainian economy in the context of systematic hybrid threats to economic security, external aggression, and active development of the information economy is especially important and urgent.

Publications of a number of domestic and foreign scientists are devoted to the study of basic provisions in the field of innovation and technological activity., in particular, such as R. Brown (1994), K. Buzhymska (2011), L. Fedulova (2010), L. Lisovska (2010), S. Lykholat (2019), N. Yasmina (2010) and others. Problems that relate directly to the technological competitiveness of the economy are the prerogative of research by such scientists as N. Havlovska (2019), Yu. Kindzerskyy (2013), O. Kirdina (2011) and M. Makri (2007), I. Orlyk

Regular research paper: Published 30 April 2020

Corresponding author's e-mail: s1925p@i.ua; v_zaychenko@ukr.net; kaf_mv@tu.edu.te.ua

Copyright (C) 2018 This is an open access article distributed under the Creative Commons Attribution CC-BY-NC 4.0 License. 
(2016), T. Vasyltsiv (2017), O. Vlasiuk (2016) and others. A number of publications are devoted to the coverage of the rating results of the world countries by different parameters of economic competitiveness, including technological. In the studies by S. Dutta (2019), H. Edsand (2019), O. Ilyash (2018), S. Kumar (2019), F. Missio (2016), K. Munir (2002) and others the problems of technological modernization of economy and economic growth of national economy are outlined.

Today, in Ukraine, the strategic planning system for ensuring technological competitiveness of Ukraine is practically absent, and this circumstance brings to the forefront the justification of strategic priorities of state policy in this sphere, to which the instruments and means of state regulation in Ukraine will be directed. Therefore, the aim of the article is to analyse the situation, identify regional disparities and justify the strategic priorities to ensure technological competitiveness of the Ukrainian economy.

\section{II. "THE MAP" OF DISPROPORTIONS OF INNOVATIVE AND TECHNOLOGICAL REGIONAL DEVELOPMENT}

The preliminary results of the analysis give reason to conclude that there is a rather significant disproportionate of innovation and technological activity (as one of the key prerequisites for ensuring technological competitiveness) in the regions of Ukraine, which are considered negative in terms of further projection of their influence on the formation of different levels of technological competitiveness and regional competitiveness and as a conclusion, increasing the disproportions of socio-economic development of the territories. Thus, if on average in the country the volume of sales of innovative products in 2018 amounted to 708.6 million $\mathrm{UAH}$, in Zaporizhzhia region this figure was 5.7 times larger, in Donetsk region - 4.7 times larger, in Kharkiv region - 3.6 times larger, and in Kyiv - 2.3 times larger. On the other hand, in 19 regions of the country the value of this indicator was lower than the national average. Differentiation between the region with the largest volumes of innovative products sold (Zaporizhzhia region) and the smallest values of this indicator (Rivne region) was 434.3 times [17]. Obviously, this situation does not contribute to the uniform placement and qualitative and efficient use of innovative and technological potential of the national economy.

Because of analysing the key parameters of innovation and technological activity in the regions of Ukraine, a "map" of innovation and technological development has been created (Figure 1).

In particular, there are reasons to talk about regional leaders in this field, which are Kyiv, Poltava, Dnipropetrovsk, Kharkiv, Rivne, Kirovohrad, Ternopil, and Sumy. In these regions of the country, the highest values of the share of enterprises with technological innovations were observed, as well as the growth rate of this indicator.

It is noteworthy that the high potential of innovation and technological activity is underused in such regions of the country as Donetsk, Zakarpattia, Ivano-Frankivsk, Kherson and some other regions. We draw this conclusion in view of the highest share of innovative products sold. However, in these regions there is no high level of technological innovation activity.

Figure 1. Positioning The Regions Of Ukraine By The Share OF ENTERPRISES WiTH TECHNOLOGICAL INNOVATIONS, THE RATE OF ITS GROWTH AND THE SHARE Of REALIZED INNOVATIVE PRODUCTS IN THE TOTAL Volume OF INDUSTRIAL PRODUCTS SOLD IN 2018

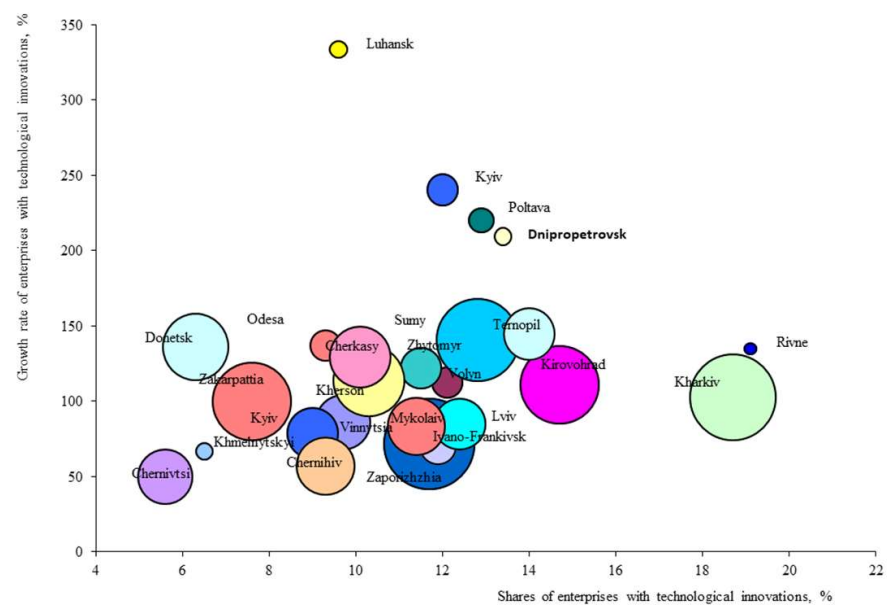

compiled according to Naukova ta innovatsiyna diyal'nist' Ukrayiny, 2017 (2018)

In defining the strategic priorities of the state policy of ensuring the technological competitiveness of the Ukrainian economy, it is necessary to take into account the present objectively existing challenges (they are the consequences) of global competition. First, it is necessary to consider the high level of dependence of the domestic economy on global stability, the absence of deep upheaval, political, financial, economic, and demographic and other crises. This conclusion is confirmed by the high level of raw materials exports and low value added products

\section{HE ROLE OF STATE POLICY IN SHAPING TECHNOLOGICAL COMPETITIVENESS OF THE UKRAINIAN ECONOMY}

At the same time, the state policy of ensuring technological competitiveness at the present stage of functioning of the economy of Ukraine is practically not implemented. Ukraine lacks a strategy for innovation and technological development of the economy and does not realize programs to support technological activity in the basic sectors of the economy, and the problems of technological development are not given sufficient attention at the regional and local levels. In fact, the question is about the lack of heredity of public policy in this area and the existence of zero stage of its formation, the task is to substantiate the fundamentally new strategic principles of state policy in the field of ensuring technological modernization of the real sector of our country's economy. 


\section{DETERMINATION OF STRATEGIC PRIORITIES IN ENSURING TECHNOLOGICAL COMPETITIVENESS OF THE UKRAINIAN ECONOMY}

Based on the generalization of the above, there are reasons to determine the following strategic priorities, as well as the goals of the state policy of ensuring technological competitiveness of the Ukrainian economy as in Figure 2. Therefore, first of all, it is about activating technological development of the economy as a strategic priority №1. This is a qualitative component of this priority. Quantitative refers to the increase in the number of created, implemented and used advanced technologies (including information), as well as their share in the total amount of technological processes used by economic entities, the share of advanced technologies in the total number of technologies (technological processes) in business processes of subjects in real sector of national economy.

According to the author, the strategic priority №2 is to determine the growth of the overall level of innovation activity in the Ukrainian economy. It is an increase of the share of enterprises that create and implement innovations in the total number of economic entities, increase of the level of innovation activity in the segment of small and medium-sized enterprises, creation of new innovatively active and innovatively oriented enterprises, increase of production volumes of innovative products and those, the production of which uses technological innovations, increasing the share of innovative products in the total production, sales and export of products.

Strategic priority №3 concerns the formation of a competitive market for intellectual property in Ukraine. Obviously, in the end (as the desired end result of regulation) there is the development of this market, but the competitive aspect allows to indicate the way to follow. The point is that, as the experience of countries with high levels of intellectual property development shows, it is competition and competitiveness of this market that is a leading factor in development. Undoubtedly, in the field of intellectual property, Ukraine is characterized by a number of other acute problems, first and foremost in terms of security and protection of intellectual property rights. However, there are no basic elements of the market here, even worse, there is no transparent system of supply and demand of objects, there are no platforms of communication, pricing, regulation of other aspects of legal and commercial relations between sellers and buyers, practically no sphere of mediation.

The following are the arguments in favor of determining the strategic priority №4 of the state policy of strengthening the technological competitiveness of the Ukrainian economy that is the formation of the infrastructure for supporting technological innovations. The introduction of modern technologies is a capital-intensive and organizationally complex process. It is a high cost to acquire technology (rights to technology), registration of its rights, including patenting, significant time and investment in the development, testing and implementation of technology, information and consulting support in the search for the right technological solutions and investment designing, attracting the necessary personnel (both in terms of research and development and its implementation in production and business processes), services related to technology expertise, technology projects, approvals of new technologies and / or models of products in the bodies of state standard, and certification.

Infrastructure elements specialize in these and other issues (which also includes research institutes, design bureaus, innovation and technology firms, specialized financial and investment entities, clusters of all kinds, technoimplementation zones, technological incubators, etc.). Based on the above, the question of the formation and capacity of the elements of the infrastructure of technological development of the economy is impartially important. According to the leading foreign experience, the presence and high capacity (financialinvestment, organizational, personnel, legal, professionalmanagement, and scientific-research) of the elements of the innovation-technological infrastructure is one of the basic factors of activation and support of technological development in the country.

Priority №5 above is about improving competition and doing business. This, according to the author, is one of the most important tasks, because in the conditions of monopolization of markets and economic resources, economic agents are objectively not interested in technological activities. They have markets for standard products and almost without competition, they produce and sell them.

We need an active and prudent state policy focused on achieving certain shifts and changes, which will result in Ukraine's positioning in the ratings of Global Competitiveness, Economic Freedom, Doing business, Perception of Corruption, etc.

\section{CONCLUSIONS}

Implementation of the state policy in the sphere of technological competitiveness of the Ukrainian economy should be a clearly planned and managed process, which requires the definition of its purpose and strategic priorities, which will form all other components of planning. Based on these principles, the strategic goal of the state policy of ensuring technological modernization of the Ukrainian economy is strengthening of external and internal technological competitiveness of economy by means of development of internal competition and strengthening of competitiveness of production on the basis of advanced technological innovations and information technologies, system support for elements of innovative infrastructure, formation and realization of intellectual and human potential of technological development of economy.

The following strategic public policy priorities are aimed at achieving this goal: intensification of technological development of economy, growth of general level of innovative activity, formation of competitive market of intellectual property, development of infrastructure for support of technological innovation, improvement of resource provision of innovation activity, improvement of parameters of competition and doing business. 
FIGURE 2. CHALLENGES, FACTORS, STRATEGIC GOAL AND PRIORITIES OF THE STATE POLICY OF ENSURING TECHNOLOGICAL COMPETITIVENESS OF THE UKRAINIAN ECONOMY

\section{Current Consequences-Challenges of Global Competition}

Increasing dependence of national economy development on global crises, financial and economic instability as a result of commodity export orientation;

- increase of external expansion into the internal markets of the countries due to the processes of globalization, including financial and economic, digitization, development of the information economy;

- increasing dependence of the economic development of countries under pressure of debt, influence of transnational industrial-financial groups:

increase of import dependence of industrially "weak" economies;

- deterioration of the quality and structure of intellectual and human resources for the economy development due to high external labour migration;

destabilization of the economic development of the regions by means of military conflicts and hybrid attacks

- formation of critical imbalances of regional development through different technological structures of the states.

\begin{tabular}{|c|c|c|c|c|c|}
\hline$\downarrow$ & $\downarrow$ & $\downarrow$ & $\downarrow$ & $\downarrow$ & $\downarrow$ \\
\hline \multicolumn{6}{|c|}{$\begin{array}{l}\text { Factors-reasons of unpreparedness of the economy for competition in the context of accelerating the pace of } \\
\text { innovation and technological activity and development of information economy }\end{array}$} \\
\hline$\downarrow$ & $\downarrow$ & $\downarrow$ & $\downarrow$ & $\downarrow$ & $\downarrow$ \\
\hline $\begin{array}{l}\text { Neglect of the } \\
\text { advanced } \\
\text { technologies by } \\
\text { enterprises, } \\
\text { increase of added } \\
\text { value }\end{array}$ & $\begin{array}{l}\text { Monopolization } \\
\text { of markets with } \\
\text { consequences of } \\
\text { neutralization of } \\
\text { innovative factor } \\
\text { of business } \\
\text { competitiveness }\end{array}$ & $\begin{array}{l}\text { Underdevelopme } \\
\text { nt of the } \\
\text { intellectual } \\
\text { property market, } \\
\text { the system of } \\
\text { intellectual capital } \\
\text { growth }\end{array}$ & $\begin{array}{l}\text { Lack of adequate } \\
\text { infrastructure } \\
\text { support for } \\
\text { innovation and } \\
\text { technological } \\
\text { activity }\end{array}$ & $\begin{array}{l}\text { Limited financial } \\
\text { investment and } \\
\text { other resource } \\
\text { support for } \\
\text { innovative } \\
\text { development }\end{array}$ & $\begin{array}{l}\text { Unformed } \\
\text { competitive } \\
\text { environment, } \\
\text { high level of } \\
\text { transaction and } \\
\text { transformation } \\
\text { costs }\end{array}$ \\
\hline$\frac{1}{t}$ & $\frac{1}{1}$ & $\downarrow$ & $\downarrow$ & 1 & 1 \\
\hline \multicolumn{6}{|c|}{$\begin{array}{c}\text { Strategic qualitative and quantitative priorities of the state policy of ensuring technological competitiveness of the } \\
\text { national economy }\end{array}$} \\
\hline $\begin{array}{l}\text { * Increase in the } \\
\text { number and } \\
\text { share of } \\
\text { advanced and } \\
\text { information } \\
\text { technologies, } \\
\text { including the } \\
\text { business } \\
\text { processes of } \\
\text { entities in the } \\
\text { real economy }\end{array}$ & $\begin{array}{l}\text { 4. Increase in the } \\
\text { share of } \\
\text { innovative } \\
\text { enterprises of } \\
\text { basic } \\
\text { activities, } \\
\text { realized } \\
\text { innovative } \\
\text { products }\end{array}$ & $\begin{array}{l}\text { 3. Formation of a } \\
\text { competitive } \\
\text { market for } \\
\text { intellectual } \\
\text { propertt } \\
\text { - Complete } \\
\text { elimination of } \\
\text { security and } \\
\text { protection problems } \\
\text { of objects of } \\
\text { intellectual property } \\
\text { rights, ensuring } \\
\text { transparency of the } \\
\text { market and } \\
\text { increasing its } \\
\text { capacity }\end{array}$ & $\begin{array}{l}\text { 4. Formation of } \\
\text { technological } \\
\text { innovation support } \\
\text { infrastructure } \\
\text { + Availability of } \\
\text { supporting } \\
\text { elements of all } \\
\text { stages of the } \\
\text { innovation } \\
\text { process, in } \\
\text { particular in the } \\
\text { spatial and } \\
\text { structural aspect }\end{array}$ & \begin{tabular}{||l} 
5. High level of \\
resource supply \\
of innovative \\
activity \\
\& Increased \\
cooperation \\
between real sector \\
entities and research \\
institutes, creation \\
of technology \\
transfer centres and \\
financial support for \\
innovation
\end{tabular} & $\begin{array}{l}\text { 6. Improving } \\
\text { competition and } \\
\text { doing business } \\
+ \text { Increases in } \\
\text { ratings: Global } \\
\text { Competitiveness, } \\
\text { Economic } \\
\text { Freedom, Doing } \\
\text { Business, } \\
\text { Perception of } \\
\text { Corruption; } \\
\text { introduction of the } \\
\text { Competition Index } \\
\text { in Ukraine }\end{array}$ \\
\hline
\end{tabular}

Strategic goal of public policy

strengthening of external and internal technological competitiveness by means of development of internal competition and strengthening of competitiveness of production on the basis of advanced technological innovations and information technologies, systematic support of elements of innovative infrastructure, formation and realization of intellectual and human potential of technological development of economy 


\section{REFERENCES}

Brown, R. L. (1994). Technological innovation's impact on market structure and industry profitability. The Journal of High Technology Management Research, 5 (1), 123-140. https://doi.org/10.1016/1047-8310(94)90017-5.

Buzhymska, K. (2011). Some components of the theoretical and methodological basis of innovative technological modernization. Bulletin of Zhytomyr State Technological University, 50 (4), 113-119.

Dutta, S., Lanvin, B. \& Wunsch-Vincent, S. (2019). Global Innovation Index 2019: Energizing the World with Innovation. Ithaca, Fontainebleau, and Geneva: Cornell University, INSEAD, and WIPO.

Edsand, H.-E. (2019). Technological innovation system and the wider context: A framework for developing countries. Technology in Society, 58, 101-115. https://doi.org/10.1016/j.techsoc.2019.101150.

European Commission (2019). Europe 2020. A strategy for smart sustainable and inclusive growth. Retrieved December 17, 2019 from: https://www.//ec.europa.eu/europe2020/index en.htm

European Commission (2019). Innovation Scoreboards: The innovation performance of the EU and its regions is increasing Retrieved February, 12, 2020

https://ec.europa.eu/commission/presscorner/detail/en/IP_19_2991.

from:

Fedulova, L. I. (2010). Technology policy in the system of economic development strategy. Economics and forecasting, 1, 22-38.

Havlovska, N., Rudnichenko, Y., Lisovskyi, I. (2019). Transformation processes in the system of providing economic security of investment activities of industrial enterprises. Baltic Journal of Economic Studies, 5 (2), 18-23. https://doi.org/10.30525/2256-0742/2019-5-2-18-23.

Ilyash, O., Dzhadan, I. \& Ostasz, G. (2018). The influence of the industry's innovation activities indices on the industrial products' revenue of Ukraine. Economics and Sociology, 11 (4), 317-331. https://doi.org/10.14254/2071 789X.2018/11-4/21.

Kindzerskyy, YU. V. (2013). Industry of Ukraine: strategy and policy of structural and technological modernization. Kyiv: NAS of Ukraine.

Kirdina, O. H. (2011). Restrictions and guidelines of technological and technological development of Ukraine in the conditions of globalization. Marketing and Innovation Management, 4 (1), 179-184.

Kumar, S., \& Singh, B. (2019). Barriers to the international diffusion of technological innovations. Economic Modelling, 82, 74-86. https://doi.org/10.1016/j.econmod.2019.08.015

Lisovska, L. S., \& Lushchak, N. S. (2010). Analysis of ways of increasing technological competitiveness of Ukraine. Bulletin of the National university «Lviv Polytechnic», 683, 364-370.

Makri, M., \& Lane, P. J. (2007). Responding to technological maturity: A sociocognitive model of science and innovation in technological communities. The Journal of High Technology Management Research, 18 (1), 1-14 https://doi.org/10.1016/j.hitech.2007.03.001.

Missio, F. J., \& Gabriel, L. F. (2016). Real exchange rate, technological catching up and spillovers in a balance-of-payments constrained growth model. EconomiA, 17 (3), 291-309. https://doi.org/10.1016/j.econ.2016.09.008.

Munir, K. A., \& Phillips, N. (2002). The concept of industry and the case of radical technological change. The Journal of High Technology Management Research, 13 (2), 279-297. https://doi.org/10.1016/S1047-8310(02)00046-9.

Naukova ta innovatsiyna diyal'nist' Ukrayiny, 2017 (2018) [Scientific and Innovative Activities of Ukraine, 2018]. Kyiv: DSSU. 366.

Orlyk, I. O., Vasyltsiv, T. G., Rudyk, S. A. (2016). Mechanisms and means of intensification of the innovative development of enterprises of retail trade. Bulletin of Khmelnytsky National University. Economic sciences, 1, 102-109.

The White House Washington (2017). National Security Strategy of the United States of America. Retrieved January 14, 2020 from
https:/www.whitehouse.gov/wp-content/uploads/2017/12/NSS-Final-12-182017-0905-2.pdf.

The World Bank (2019). The Knowledge Economy Index 2019. Retrieved February, $12, \quad 2020$ from: https://knoema.com/atlas/topics/WorldRankings/World-Rankings/Knowledge-economy-index

Lyholat, S., Vasyltsiv, T., Ivaniuk, U., Brych, V. (2019). Tools of small business development in the mountainous regions of the Carpatian region of Ukraine. Arctic, 72 (11), 70-82.

Vasyltsiv, T. G., Shehlovych, A. M., Vasyltsiv, V. V. (2017). Financial and economic instruments of stimulation of development of IT-sphere of Ukraine. Economic discourse, 4, 128-136

Vlasiuk, O. (2016). System transformations of the national economy: challenges and expectations. University of Economy Publishing House, Bydgoszcz.

World Economic Forum (2019). The Global Competitiveness Report 2019. Retrieved February, 05, 2020 from: http://www3.weforum.org/docs/WEF_TheGlobalCompetitiveness Report2019.pdf.

Yasmina, N. M., \& Augusto, L.-C. (2010). The Innovation Capacity Index: Factors, Policies, and Institutions Driving Country Innovation. The Innovation for Development Report 2009-2010., London: Palgrave Macmillan. https://doi.org/10.1057/9780230285477 